\title{
Philip Morris promotional gimmick kills two in Poland
}

Smoking is a paediatric disease that usually takes decades to claim its victims. Yet the promotion of cigarettes-particularly American cigarettes in Poland-can kill young people instantly.

In the first six months of 1997, five sales representatives at Philip Morris Poland were killed and another critically injured in three separate accidents involving company cars. At first glance it seems that one of the world's most aggressive marketing programmes and some of the world's deadliest roads are simply a combination destined to produce repeated tragedies. But a closer look reveals that, in the third and most horrific accident, the company's gross and perhaps criminal negligence greatly increased the risk to its young employees.

Let's say you're a marketing manager at the world's leading transnational tobacco company, and you're working in one of those backward little post-communist countries-for example, Poland. Your flagship brand, despite your best efforts and relentless promotional campaigning, just isn't as popular among Polish youth as you would like it to be. What do you do?

Even more promotions? Sure, the gadgets, contests, and cigarette giveaways must continue. (Never mind that you promised four years ago back home in the United States to stop handing out free samples. Poland ain't home, is it? Home is now a tobacco war zone. Poland, God love it, is one of the new Promised Lands.) But these promotional tools are standard. You need something more, something with a little zip, a little flare. Something to make

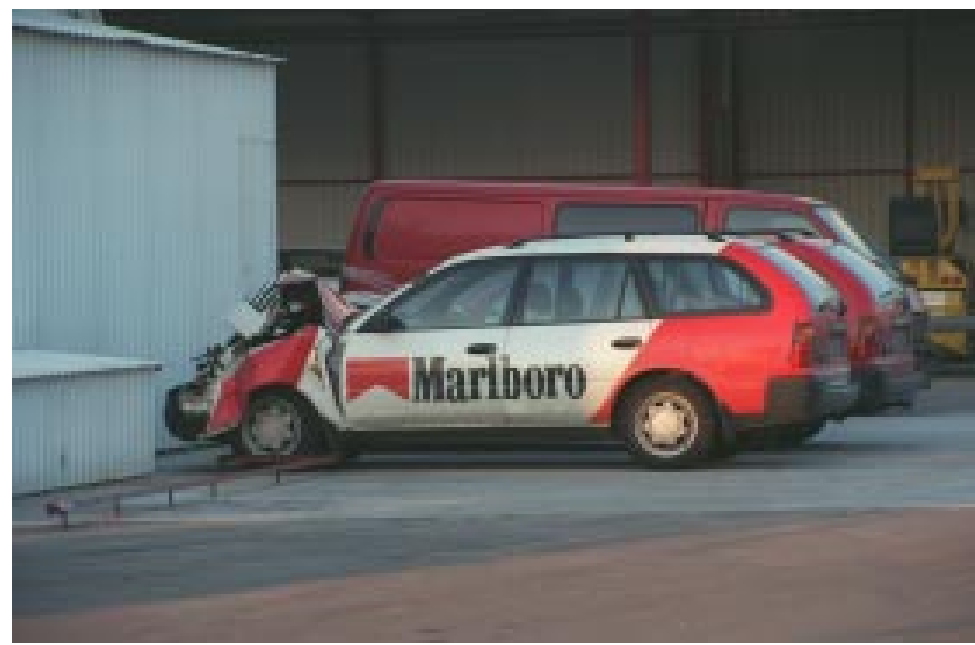

This Philip Morris vehicle, photographed on a company lot near Warsaw in February 1998, may be an example of the wreckage (and carnage) resulting from high-speed tobacco marketing in Poland. (Photo credit: P Wrabec.) heads turn-especially heads that are young and impressionable.

Got it! You know those trick matches that you can light on your jeans? The ones used for cheap effect in films (kind of like smoking itself)? Well, there's your flare. Your fresh-faced sales reps will no longer simply offer a free smoke to your youthful targets in Polish dance clubs, pubs, and cafés. They'll now offer a quick, eye-catching light to go with it.

But wait a minute. Does anybody outside of Hollywood even produce matches like that? They are, by design, highly flammable. It's hard to imagine anybody getting a licence to make them. It certainly wouldn't be possible back home or in western Europe. (Never mind. This ain't home or western Europe, remember?! You've got the idea and you've got the money. Somebody in Poland will make the trick matches for you. What a great country!)

Okay, you're almost ready. To complete the road show, you'll need a few more eager young recruits, 18-25 years of age, and of course a flashy new car. Put it all together now: the car, three young sales reps, a whole bunch of smokes for them to give away, and the matches. Yes, lots of matches, lots of those Hollywood trick-stick matches ....

Time to hit the road. Night is falling and the youngsters are heading to town. Hurry now.

For details about what happened next on a fune evening last year, below are some excerpts from an article in a Polish newspaper (Zycie, 9 September 1997).

"God! Help!"

She tries to get out but the door won't open. Everything is ablaze - the seats, the cartons of cigarettes and the matches.

"Adam! Beata!"

The girl screams but there's no answer. The heads of her two companions lean motionless against their seat belts. The flames engulf her legs. Suddenly the window is smashed and she sees hands reaching in. They grab her and pull.

She's outside. Through the smoke she once again sees the bold logo on the side of the car: Marlboro.

Nineteen-year-old Katarzyna survived the accident but spent more than two months in the hospital recovering. Adam, a 25-year-old "promotor," and 24-year-old "hostess" Beata both perished.

They had attempted to pass a car which at the same time tried to pass another. This forced their Marlboro car off the left side of the road, where it hit a mileage marker and then a tree, whereupon it immediately burst into flames. 
Mariusz (a friend of Adam's) takes a box of matches from his backpack. It is decorated with a familiar cigarette logo and part of a cowboy boot. "We got these from Adam's parents. They're so easy to light - a great promotion." He takes one out and lights it on the pavement; a second one on his jeans. Then he bends down, puts the whole box on the ground and hits it with his fist. It explodes and is immediately engulfed in flames. "They had at least a thousand of those boxes in the car."

The director of the Polmatch match factory in Sianow: "I knew something like this would happen with those matches. That's why we wouldn't make them. The only factory in the country that agreed to make them was EuroMatch. It's a scandal that something like that could be produced at all."

An explosive materials expert from Warsaw Polytechnic: "It's not illegal to produce such matches, but Philip Morris broke transport laws by allowing them to be shipped without adequate safety packaging. Those matches can only be transported in reinforced cartons and must be certified by the Packaging Institute."

Piotr (another friend of Adam's): "He was so happy then. Instead of sitting in a chair, he was on the road, in a great car, driving $200 \mathrm{~km}$ per day. $\mathrm{He}$ organized cigarette promotions in pubs, clubs and cafés. The company paid him just to talk to people and hand out packs of L\&Ms."

Ania (an old school friend): "Adam stopped by once after work, around midnight, in a beautiful company sweater. His eyes were very dark and tired, but happy_like the Devil's."

"They complimented me today," he said. "Listen, I think I'm starting to believe in myself. The boss told me I'm outgoing, direct and clever-just the kind of person they need."

Artur (another friend): "He dropped out of college because the job was too demanding. Then he stopped joining us for a beer on Sundays because he had to do all that paperwork."

Jacek (a former PM Poland sales rep): "The routine? Take for example the Marlboro Adventure Team promotion. Every evening we had to get at least 400 people to fill out those coupons and take part in the contest. The prize was a trip to America. Who wouldn't want to try? Everybody filled them out, 16-year-olds, 18-year-olds."

Kasia (Adam's sister): "For two weeks after his death, not a word came from the company-so we went to them. My parents and I went straight to the director, a man of
Greek origin. My father was very angry but managed to say slowly in English, 'My son is dead. He was working for you but you have nothing to say. You haven't phoned. You haven't even bothered to tell me to kiss my own ass."”

"They started to take some interest in us after our visit."

Adam's mother: "We hired a lawyer. The head of PM must understand that you cannot do whatever you want to people and then forget about it. How can you fill a car with explosive matches and then tell kids to drive it? That's just not right."

Tomek (another former PM Poland "promotor"): "I wouldn't be so sure that his family will win. There's big money at stake here. PM bought the factory in Cracow for $\$ 300$ million, as much as Daewoo paid for the car factory in Warsaw. Furthermore, central Europe is the world's best tobacco market. Smoking rates are falling elsewhere, but they're rising here. The company will fight for its interests."

Jacek: "The tobacco companies have it better here than anywhere else. The Polish legal system allows them to do as they like. In the States these days they're paying lots of money for the harm done by their products. So they're coming here, to Poland, the Czech Republic, Hungary - to the new Promised Lands."

Tomek: "The labour code doesn't protect people like us. When I worked for PM we had to visit eight clubs a night. We spent at least half an hour in each one and had to do a lot of paperwork on the spot. Then the quotas were raised to ten and later twelve stops per night. It must be even more now. The reps ran like crazy to keep up, and on top of this they had 'bombs' in their cars."

At the PM factory in Cracow, nobody was able to answer the question, "Why were highly flammable, uncertified matches carried in your cars and why were your employees not warned about the danger?"

Epilogue: On the day of her death, Beata, an only child, was a week away from completing her degree in physical education.

SCOTT THOMPSON Health Promotion Foundation and Center for Cancer Epidemiology and Prevention, ul WK Roentgena 5, 02-781 Warszawa, Poland

thompson@coi.waw.pl 